JURNAL

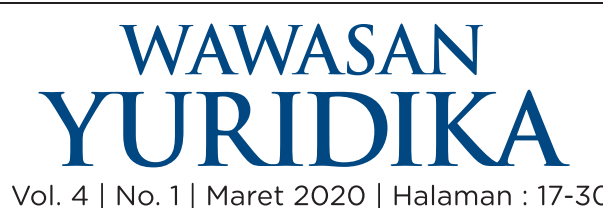

Vol. 4 | No. 1 | Maret 2020 | Halaman : 17-30

Nationally Accredited Journal Decree No. 36/E/KPT/2019, Dated 13rd December 2019 http://ejournal.sthb.ac.id/index.php/jwy

\title{
Penanggulangan Tindak Pidana Kekerasan dalam Rumah Tangga di Kota Makassar
}

\author{
Sutiawati ${ }^{1}$, Nur Fadhilah Mappaselleng ${ }^{2}$ \\ ${ }^{12}$ Fakultas Hukum, Universitas Muslim Indonesia, Makassar, Indonesia \\ $\triangle$ Corresponding Author: sutiawati.hukum@umi.ac.id
}

\section{Info Artikel:}

DOI: 10.25072/jwy.v4i1.315

Kata Kunci:

Kekerasan; Rumah Tangga; Kota Makassar.

\begin{abstract}
Abstrak
Fenomena kekerasan dalam rumah tangga mengalami peningkatan dari segi kuantitas dan kualitas, sehingga membutuhkan perhatian yang lebih serius. Penelitian ini bertujuan untuk mengetahui dan menganalisis faktor yang menyebabkan terjadinya tindak pidana kekerasan dalam rumah tangga, serta upaya penanggulangannya di Kota Makassar. Penelitian ini bersifat deskriptif dengan jenis penelitian yuridis empiris yang berlokasi di Kota Makassar. Penelitian ini menggunakan data primer dan data sekunder, teknik pengumpulan data studi kepustakaan dan wawancara, kemudian dianalisis secara kualitatif. Hasil penelitian menunjukkan bahwa faktor penyebab terjadinya kekerasan dalam rumah tangga di Kota Makassar adalah penegakan hukum, rendahnya kesadaran hukum, masih kuatnya budaya patriarki, kondisi ekonomi/kemiskinan, lingkungan sosial, dan kebiasaan minuman keras. Upaya penanggulangan kekerasan dalam rumah tangga di Kota Makassar menempuh upaya preemtif, preventif, dan represif.
\end{abstract}

Keywords: Violence; Household; Makassar City.

\section{Abstract}

The phenomenon of domestic violence has increased in terms of quantity and quality, so it requires serious attention. The research aims is to find out and analyze the factors that causes criminal acts of domestic violence and the efforts to prevent crime in domestic violence in the city of Makassar. This research is a descriptive research with empiric juridical research, located in Makassar City. This study uses primary data and secondary data, the technique of collecting literature and interview study data, then analyzed qualitatively. The results showed that the factors causing domestic violence in Makassar were law enforcement, low legal awareness, strong patriarchal culture, economic conditions/poverty, social environment, and drinking habits. Efforts to prevent domestic violence in Makassar have taken preemptive, preventive and repressive measures. 


\section{A. PENDAhUluan}

Fenomana kasus kekerasan dalam rumah tangga (selanjutnya disebut KDRT) saat ini terjadi peningkatan, dari segi kuantitas dan segi kualitas. ${ }^{1}$ Fenomena tersebut menjadi perhatian serius dan semua pihak agar dapat memahami segala bentuk kejahatannya dan faktor-faktor penyebabnya, serta upaya penanggulangan KDRT. ${ }^{2}$ Bentuk KDRT yang terjadi sangat bervariasi, seperti kekerasan fisik, psikis, seksual, dan kekerasan berupa penelantaran. Berbagai bentuk kejahatan tersebut merupakan kejahatan yang dilarang dan diancam hukuman sebagaimana diatur dalam Undang-Undang Nomor 23 Tahun 2004 tentang Penghapusan Kekerasan Dalam Rumah Tangga (selanjutnya disebut UU PKDRT) yang bertujuan agar korban KDRT terutama perempuan mendapatkan perlindungan hukum. ${ }^{3}$

Kekerasan terhadap perempuan juga merupakan fenomena sosial yang pada saat ini menjadi keprihatinan berbagai pihak. ${ }^{4}$ Dalam perkembangannnya, korban KDRT sulit mengadukan penderitaan yang dialaminya kepada penegak hukum, karena kuatnya pandangan bahwa perlakuan kasar suami kepada istri merupakan bagian dari peristiwa privat (urusan rumah tangga). ${ }^{5}$

Penegakan hukum terhadap pelaku KDRT kepada istri dapat menggunakan aturan-aturan hukum, baik dalam Kitab Undang-Undang Hukum Pidana (KUHP), Undang-Undang Nomor 1 Tahun 1974 tentang Perkawinan, maupun UU PKDRT.

Komisi Nasional Anti Kekerasan terhadap Perempuan dalam siaran pers catatan akhir tahun (CATAHU) Komnas Perempuan 2019 merilis bahwa pengaduan kasus kekerasan terhadap perempuan pada tahun 2018 meningkat $14 \%$ dari tahun sebelumnya. ${ }^{6}$ Begitu halnya yang terjadi di Kota Makassar, kasus KDRT yang dilaporkan kepada Unit Perlindungan Perempuan dan

1 Hamidah Abdurrachman, "Perlindungan Hukum Terhadap Korban Kekerasan Dalam Rumah Tangga dalam Putusan Pengadilan Negeri Sebagai Implementasi Hak-Hak Korban," Ius Quia Iustum Law Journal 17, No. 3 (2010): 475-491, hlm. 476.

2 Estu Rakhmi Fanani, “Undang-Undang Nomor 23 Tahun 2004 tentang Kekerasan dalam Rumah Tangga, Antara Terobosan Hukum dan Fakta Pelaksanaannya," Jurnal Legislasi Indonesia 5, No. 3 (2008): 1-8, hlm. 2.

3 Rena Yulia Nuryani, "Perlindungan Hukum Terhadap Korban Kekerasan dalam Rumah Tangga dalam Penegakan Hukum," Mimbar: Jurnal Sosial dan Pembangunan 20, No. 3 (2004): 311-326, hlm. 311.

4 Siti Rohmah Nurhayati, "Atribusi Kekerasan dalam Rumah Tangga, Kesadaran Terhadap Kesetaraan Gender, dan Strategi Menghadapi Masalah pada Perempuan Korban Kekerasan dalam Rumah Tangga," Jurnal Psikologi UGM 32, No. 1 (2005): 1-13, hlm. 1-2.

5 La Jamaa, "Perlindungan Korban Kekerasan dalam Rumah Tangga dalam Hukum Pidana Indonesia," Jurnal Cita Hukum II, No. 2 (2014): 249-272, hlm. 250.

6 Reporter Komnas Perempuan, "Hentikan Impunitas Pelaku Kekerasan Seksual dan Wujudkan Pemulihan yang Komprehensif Bagi Korban," Siaran Pers Catatan Tahunan (CATAHU) Komnas Perempuan, 2019, https://www.komnasperempuan.go.id/read-news-siaran-pers-catatan-tahunancatahu-komnas-perempuan-2019, diakses 1 Maret 2020. 
Anak Kepolisian Resor Kota Besar Makassar (selanjutnya disebut Unit PPA Polrestabes Makassar) dari tahun 2015 sampai dengan Agustus tahun 2017, sebanyak 142 kasus. Kekerasan fisik merupakan jenis KDRT yang paling banyak dilaporkan, sedangkan kekerasan seksual merupakan jenis kekerasan yang sedikit dilaporkan.

Kekerasan fisik merupakan jenis kekerasan yang paling mudah dalam pembuktiannya, sebaliknya kekerasan seksual tidak mudah dalam mengumpulkan barang bukti. Kekerasan terhadap perempuan yang berakibat timbulnya kesengsaraan atau penderitaan secara fisik, seksual, psikologis, dan atau penelantaran rumah tangga termasuk ancaman untuk melakukan perbuatan, pemaksaan, atau perampasan kemerdekaan secara melawan hukum dalam lingkup rumah tangga. Tindakan ini seringkali dikaitkan dengan penyiksaan, baik fisik maupun psikis yang dilakukan oleh orang yang mempunyai hubungan dekat. ${ }^{7}$

Kekerasan fisik yang dilaporkan ke Unit PPA Polrestabes Makassar selama tahun 2015-Agustus 2017, sebanyak 133 kasus. Kekerasan fisik adalah yang paling sering dilaporkan, yakni sebanyak 101 kasus. Bentuk kekerasan fisik adalah pemukulan, baik yang menggunakan tangan maupun menggunakan alat. Kekerasan psikis yang dilaporkan sebanyak 8 kasus, dalam bentuk caci maki, menyebut dengan kata tak senonoh, perselingkuhan, mengancam akan menceraikan, dan memisahkan dengan anak. Penelantaran rumah tangga dilaporkan sebanyak 33 kasus.

Berdasarkan deskripsi di atas, maka perlu dikaji dalam bentuk penelitian mengenai upaya penanggulangan tindak pidana KDRT di Kota Makassar. Penelitian ini bertujuan untuk mengetahui dan menganalisis faktor yang menyebabkan terjadinya tindak pidana kekerasan dalam rumah tangga, serta upaya penanggulangannya di Kota Makassar

\section{B. METODE PENELITIAN}

Penelitian ini bersifat deskriptif dengan jenis penelitian yuridis empiris yang berlokasi di Kota Makassar, yaitu pada Unit PPA Polrestabes Makassar dan pusat pelayanan terpadu pemberdayaan perempuan dan anak (P2TP2A) Kota Makassar. Pemilihan lokasi penelitian dengan pertimbangan kedua instansi yang melakukan penegakan hukum, serta berpeluang melaksanakan upaya penanggulangan tindak pidana kekerasan dalam rumah

B. Rudi Harnoko, “Dibalik Tindak Kekerasan Terhadap Perempuan,” Muwazah 2, No. 1 (2010): 181188, hlm. 182. 
tangga. Penelitian ini menggunakan dua jenis data, pertama adalah data primer, yaitu data yang berasal dari sumber data utama berupa wawancara dengan informan di lokasi penelitian. Data informan bersumber dari penyidik Unit PPA Polrestabes Makassar, korban KDRT yang melapor ke Unit PPA Polrestabes Makassar, dan petugas di P2TP2A Kota Makassar. Kedua data sekunder, yaitu data yang berasal dari bahan bahan pustaka yang bersumber dari peraturan perundang undangan, hasil penelitian, artikel ilmiah, dan buku (literatur) yang berkaitan dengan upaya penanggulangan tindak pidana KDRT. Teknik pengumpulan data yang digunakan dalam penelitian ini adalah studi kepustakaan dan wawancara. Analisis data yang digunakan dalam penelitian ini adalah analisis kualitatif.

\section{HASIL DAN PEMBAHASAN}

1. Faktor Penyebab Terjadinya Tindak Pidana KDRT di Kota Makassar

KDRT merupakan tindakan yang sering terjadi, namun sangat sulit untuk diketahui. ${ }^{8}$ Faktor penyebab pertama adalah KDRT terjadi dalam lingkup kehidupan rumah tangga yang dipahami sebagai urusan yang bersifat privasi, di mana orang lain tidak boleh ikut campur (intervensi). Faktor kedua, korban (istri/anak) adalah pihak yang secara struktural lemah dan mempunyai ketergantungan, khususnya secara ekonomi dengan pelaku (suami). ${ }^{9}$

Berdasarkan hasil penelitian pada kantor kepolisian resor Kota Besar Makassar tahun 2016-2018, terdapat 535 kasus KDRT yang dilaporkan, sebagaimana data pada tabel 1 sebagai berikut:

Tabel 1

Kasus KDRT di Kota Makassar Tahun 2016-2018

\begin{tabular}{clccccc}
\hline No. & \multicolumn{1}{c}{ Jenis-Jenis KDRT } & 2016 & 2017 & 2018 & Jumlah \\
\hline 1 & Kekerasan Fisik & 67 & 76 & 81 & 224 \\
2 & Kekerasan Psikis & 41 & 40 & 42 & 123 \\
3 & Kekerasan Seksual & 26 & 28 & 31 & 85 \\
4 & Penelantaran Keluarga & 29 & 36 & 38 & 103 \\
\hline \multicolumn{2}{r}{ Jumlah } & 163 & 180 & 192 & 535 \\
\hline
\end{tabular}

Sumber Data: Polrestabes Makassar Tahun 2019

8 Resti Arini, “Kekerasan Psikis dalam Rumah Tangga Sebagai Suatu Tindak Pidana," Lex Crimen II, No. 5 (2013): 32-42, hlm. 32.

9 Lely Wulandari, “Kebijakan Penanganan Kekerasan dalam Rumah Tangga Melalui Mediasi Penal," LAW REFORM 4, No. 1 (2008): 1-19, hlm. 2. 
Berdasarkan data pada tabel 1, dapat dijelaskan bahwa kasus KDRT yang terjadi di Kota Makassar dan dilaporkan di Polrestabes Makassar meliputi semua jenis kekerasan yang diatur dalam UU PKDRT. Pada kurun waktu tahun 2016 sampai dengan tahun 2018, terjadi 535 kasus KDRT yang terdiri dari kekerasan fisik sebanyak 224 kasus, kekerasan psikis sebanyak 123 kasus, kekerasan seksual sebanyak 83 kasus, dan penelantaran keluarga sebanyak 103 kasus. Kasus KDRT yang terjadi di Kota Makassar masih didominasi oleh konflik antara suami dan istri. Korban lebih banyak tertuju pada istri.

Dari 4 (empat) jenis KDRT yaitu kekerasan fisik, kekerasan psikis kekerasan seksual, dan penelantaran keluarga,terlihat bahwa kekerasan fisik merupakan jenis kekerasan yang paling tinggi angkanya dan setiap tahun mengalami peningkatan yang cukup signifikan. Sedangkan kekerasan seksual merupakan jenis KDRT yang paling rendah angka kejahatannya dan tren kenaikan kejahatannya masih rendah.

\section{a. Penegakan Hukum}

Lahirnya UU PKDRT membawa konsekuensi segala bentuk tindak pidana KDRT diselesaikan berdasarkan undangundang tersebut. ${ }^{10}$ Sebelum berlakunya
UU PKDRT, setiap bentuk kekerasan yang terjadi dalam rumah tangga diselesaikan dengan menggunakan ketentuan pidana yang ada dalam KUHP. Bahkan pada saat awal UU PKDRT diberlakukan, aparat penegak hukum masih menggunakan KUHP dengan pertimbangan UU PKDRT masih tergolong baru. Penegak hukum masih kesulitan untuk mengumpulkan bukti dari saksi, maupun saksi korban, atau alat bukti yang lain. Penegak hukum sudah memahami betul kekurangan dan kelebihan KUHP, cara mencari bukti yang cepat dan mudah.

UU PKDRT merupakan terobosan hukum yang positif dalam ketatanegaraan Indonesia, sehingga persoalan pribadi telah masuk menjadi wilayah publik. Pada masa sebelum UU PKDRT ada, kasus-kasus KDRT sulit untuk diselesaikan secara hukum. Hukum pidana Indonesia tidak mengenal KDRT, bahkan kata-kata kekerasan pun tidak ditemukan dalam KUHP. Kasus-kasus pemukulan suami terhadap istri atau orangtua terhadap anak diselesaikan dengan menggunakan pasal-pasal tentang penganiayaan, yang kemudian sulit dipenuhi unsur-unsur pembuktiannya, sehingga kasus yang diadukan tidak lagi ditindaklanjuti.

\footnotetext{
10 Rena Yulia, “Implementasi Undang-Undang Nomor 23 Tahun 2004 Tentang Penghapusan Kekerasan dalam Rumah Tangga dalam Proses Penegakan Hukum (Sebuah Solusi dalam Perlindungan Hukum Terhadap Korban)," Pro Justitia 24, No. 3 (2006): 292-300, hlm. 292-293.
} 
Silvia Desti (jaksa fungsional Kejaksaan Negeri Jakarta Pusat) mengatakan, bahwa upaya penegakan hukum terhadap kasus KDRT terhambat dengan alasan tidak cukup bukti atau tidak adanya saksi yang menguatkan, sehingga proses hukum tidak dapat dilanjutkan. Kendala tersebut memang benar adanya, karena KDRT terjadi dalam ruang terbatas yaitu rumah. ${ }^{11}$ Walaupun semua pihak dapat melihat bahwa fakta di lapangan memang banyak terjadi KDRT, namun karena terjadi di ruang privat, maka sulit untuk menyaksikan secara langsung. ${ }^{12}$

Kebijakan dalam penegakan hukum kasus KDRT juga banyak dilakukan oleh aparat kepolisian, dalam hal ini Unit dalam hal ini Unit PPA. Pengaduan oleh korban ke sentra pelayanan kepolisian kadang tidak segera ditindaklanjuti. Biasanya aparat kepolisian menunggu beberapa hari dengan pertimbangan kemungkinan korban datang untuk mencabut laporan. Kalau pun tidak, aparat kepolisian sering menganjurkan para pihak untuk berdamai saja dan tidak melanjutkan proses penegakan hukum. ${ }^{13}$
Banyak kasus KDRT yang tidak ditangani secara langsung oleh aparat kepolisian. Bahkan, kasus KDRT yang akibatnya ringan seperti memar pada tubuh atau luka yang tidak menyebabkan halangan untuk beraktivitas, lebih banyak dipandang sebelah mata daripada kasus lainnya.

\section{b. Kesadaran Hukum}

Kesadaran hukum merupakan kewajiban setiap orang menaati aturanaturan atau norma-norma hukum. Selain norma hukum yang berlaku itu, ada pula norma-norma lainnya, yaitu norma agama, norma kesopanan, dan norma kesusilaan. Agar dapat tertib dan teratur, seharusnya selalu mematuhi norma-norma atau peraturanperaturan yang berlaku, baik dalam kehidupan bermasyarakat, berbangsa, dan bernegara. Agar masyarakat tetap terpelihara, maka haruslah norma itu dipatuhi. Setiap orang yang menghendaki hidup tertib dan tenteram harus selalu taat dan patuh terhadap hukum atau peraturan-peraturan yang berlaku di negara, lingkungan masyarakat, lingkungan kerja, dan lingkungan rumah.

\footnotetext{
11 Silvia Desti, Faktor Penyebab Terjadinya Tindak Pidana Kekerasan dalam Rumah Tangga di Kota Makassar, diwawancara oleh Sutiawati, 8 November 2019.

12 CR-7, "Pembuktian Masih Menjadi Momok Penanganan Kasus KDRT: Bagaimana Mendefinisikan Kekerasan Psikis, Apakah Dia Harus Depresi, atau Cukup Dia Mulai Gelisah?," Hukumonline.com, 2010, https://www.hukumonline.com/berita/baca/lt4b459ec464a39/kdrt/, diakses 1 Maret 2020.

13 Rita Serena Kolibonso, "Penegakan Hukum Kejahatan Kekerasan dalam Rumah Tangga," Jurnal Legislasi Indonesia 5, No. 3 (2008): 35-44, hlm. 40.
} 
Ketenteraman dan kebahagiaan dalam kehidupan sehari-hari dapat dinikmati, apabila semua anggota keluarga berperilaku tertib dan patuh pada peraturan yang ada dalam keluarga tersebut dan tidak menyelesaikan masalah dengan cara kekerasan.Jika setiap anggota keluarga memahami hak dan kewajibannya sebagai subjek hukum, maka kesadaran hukum akan semakin meningkat. Tingginya kasus tindak pidana KDRT menunjukkan masih kurangnya kesadaran hukum pelakunya. Korban terkadang tidak melaporkan KDRT yang menimpanya dengan alasan malu, aib rumah tangga, akibat KDRT tidak terlalu berat, atau takut akan ancaman/kekerasan selanjutnya oleh pelaku bila melapor.

KDRT disebabkan juga oleh rendahnyakesadaranhukum masyarakat untuk melaporkan terjadinya kasus KDRT di lingkungannya. Alasan tidak berpartisipasi karena masyarakat tidak mau turut campur dengan urusan rumah tangga orang lain, takut mendapat tindakan balas dendam dari pelaku, serta tidak mau berurusan dengan proses penegakan hukum, mulai dari kepolisian, kejaksaan, sampai pemeriksaan di pengadilan.

Makmur, koordinator tim reaksi cepat P2TP2A Kota Makassar menyatakan, bahwa rendahnya kesadaran hukum masyarakat juga sangat dipengaruhi kurangnya sosialisasi UU PKDRT, sehingga para pihak serta masyarakat tidak mengetahui hak, kewajiban, serta partisipasinya. Mereka juga tidak memahami bahaya dan dampak terjadinya KDRT. ${ }^{14}$

\section{c. Budaya}

Budaya patriarki merupakan suatu kebudayaan yang mengutamakan dan mengumpulkan kaum laki-laki, mereka merasa dirinya memiliki kontrol atas perempuan dan membuat perempuan tetap dikuasai melalui berbagai cara. Laki-laki merasa mempunyai hak menentukan norma kehidupan dan gaya kepemimpinan yang dirasa mampu terus memperkokoh dominasi dan kekuasaannya. Kekerasan terhadap istri sebagai gambaran sistem patriarki untuk meniadakan kontrol perempuan atas daya produksi, reproduksi, seksualitas, gerak perempuan, harta milik, dan sumber ekonomi lainnya.

Secara harfiah, patriarki berarti sistem yang menempatkan ayah sebagai penguasa keluarga. Istilah ini kemudian digunakan untuk menjelaskan suatu masyarakat, di mana kaum laki-laki berkuasa atas kaum perempuan dan anak-anak.

\footnotetext{
14 Makmur, Faktor Kesadaran Hukum dalam Tindak Pidana Kekerasan dalam Rumah Tangga di Kota Makassar, diwawancara oleh Sutiawati, 8 November 2019.
} 
Budaya patriarki di Sulawesi Selatan berdampak negatif bagi perempuan. Apabila nilai yang dianut dalam suatu masyarakat bersifat patriarki, maka yang muncul adalah superioritas laki-laki di hadapan perempuan. Manifestasi nilainilai tersebut dalam kehidupan keluarga adalah dominasi suami atas istri. Hidup dalam budaya patriarki meletakkan laki-laki sebagai makhluk superior dan perempuan sebagai makhluk inferior. Dengan keyakinan ini, laki-laki kemudian dibenarkan untuk menguasai dan mengontrol perempuan. Keadaan adanya penerimaan masyarakat bahwa posisi perempuan memang subordinat mengakibatkan laki-laki atau suami dengan mudah melakukan tindakan kekerasan terhadap istri juga dianggap ilegal untuk membuat perempuan tetap menjadi subordinat sekaligus sebagai bentuk penyelesaian saat terjadinya masalah antara suami istri. ${ }^{15}$

Budaya patriarki menempatkan posisi sosial kaum laki-laki lebih tinggi daripada kaum perempuan, sehingga masyarakat cenderung menganggap wajar adanya perilaku pelecehan/ kekerasan terhadap perempuan dalam bentuk sekecil apa pun. Bahkan, seringkali perempuan yang menjadi korban pelecehan justru disalahkan, misalnya karena berpakaian yang tak sesuai norma kesopanan.

\section{d. Kondisi Ekonomi/Kemiskinan}

Setiap rumah tangga pastinya tidak menginginkan terjadinya perselisihan antara suami dan istri, karena pada hakikatnya, hubungan suami-istri merupakan hubungan yang diawali dari proses perkawinan yang merupakan peristiwa penting dalam kehidupan manusia. ${ }^{16}$ Terjadinya KDRT juga sangat dipengaruhi oleh faktor sosial ekonomi. ${ }^{17}$ Status ekonomi rumah tangga, kestabilan perkawinan (marital instability), dan konflik verbal suami istri berhubungan dengan KDRT, kemiskinan, serta ketidakmampuan mencari pemecahan mengatasi kemiskinan seringkali mengakibatkan destabilisasi emosi pada suami-istri, sehingga rentan terhadap kekerasan. Tingkat perekonomian yang rendah berpengaruh terhadap munculnya ledakan-ledakan emosional. Suami yang terbatas pendapatannya harus bekerja keras untuk memperoleh tambahan pendapatan guna memenuhi kebutuhan keluarga.

\footnotetext{
15 Muhammad Arif, Faktor Penyebab Terjadinya Tindak Pidana Kekerasan dalam Rumah Tangga di Kota Makassar, diwawancara oleh Sutiawati, 8 November 2019.

16 Ilham Abbas et al., "Hak Penguasaan Istri Terhadap Mahar Sompa Perkawinan Adat Bugis Makassar (Kajian Putusan PA Bulukumba Nomor 25/Pdt.P/2011/PABlk)," Kanun: Jurnal Ilmu Hukum 20, No. 2 (2018): 203-218, hlm. 204.

17 Bhennita Sukmawati, "Hubungan Tingkat Kepuasan Pernikahan Istri dan Coping Strategy dengan Kekerasan dalam Rumah Tangga," Jurnal Sains dan Praktik Psikologi 2, No. 3 (2014): 205-218, hlm. 206.
} 
Melihat uraian di atas, dapat diketahui bahwa kemiskinan dapat memicu munculnya destabilisasi emosi pada pasangan suami-istri, kondisi seperti ini akan memudahkan terjadinya KDRT. Kebergantungan secara ekonomi oleh istri kepada suami juga memicu KDRT. Istri biasanya menerima begitu saja kekerasan yang dilakukan oleh suami dengan alasan takut tidak diberi uang untuk kebutuhan sehari-hari.

\section{e. Lingkungan Sosial}

Lingkungan sosial merupakan bagian dari tempat bermukimnya masyarakat atau lingkungan pergaulan yang dapat mempengaruhi perilaku seseorang. ${ }^{18}$ Lingkungan yang warga masyarakatnya cenderung tidak peduli dengan tindak kekerasan yang terjadi di dalam rumah tangga akan memberikan peluang bagi pelaku untuk melakukan KDRT secara terus-menerus. Korban cenderung akan mendiamkan KDRT yang dialami karena berpikir masyarakat menganggapnya persoalan biasa yang sering terjadi dalam setiap rumah tangga. Masyarakat biasanya akan bereaksi ketika KDRT yang terjadi menimbulkan akibat yang berat atau menyebabkan kematian.
Fenomena baru penyebab terjadinya KDRT adalah penggunaan media sosial. ${ }^{19}$ Berdasarkan wawancara dengan Aipda Darwis, Subnit II Unit VI (PPA) Satreskrim Polrestabes Makassar, penggunaan media sosial tidak secara bijak, banyak menyebabkan pasangan melakukan KDRT, baik itu suami atau istri. Salah satu pihak menemukan pasangan mereka bersosial media dengan laki-laki/wanita lain, sehingga menimbulkan kecemburuan yang memicu terjadinya kekerasan. ${ }^{20}$

\section{f. Minuman Keras}

Hasil wawancara yang dilakukan dengan Aipda Darwis, Subnit II Unit VI PPA Satreskrim Polrestabes Makassar, ada sebagian warga masyarakat Kota Makassar yang memiliki kebiasaan untuk minum minuman keras (Ballo). Efek meminum minuman keras dalam jumlah berlebihan selain merusak kesehatan, juga mempengaruhi tindakan seseorang. ${ }^{21}$ Dalam keadaan mabuk, seorang suami dapat melakukan kekerasan fisik kepada istri dan anaknya. Pengaruh minuman keras terhadap kekerasan yang dilakukan suami kepada istrinya, menjadikan suami

18 Rachmat Mulyana, "Penanaman Etika Lingkungan Melalui Sekolah Perduli dan Berbudaya Lingkungan," Jurnal Tabularasa Pps Unimed 6, No. 2 (2009): 175-180, hlm. 176.

19 Monica Hidajat et al., "Dampak Media Sosial dalam Cyber Bullying," Comtech 6, No. 1 (2015): 72-81, hlm. 78 .

20 Darwis, Faktor Penyebab Terjadinya Tindak Pidana Kekerasan dalam Rumah Tangga di Kota Makassar, diwawancara oleh Sutiawati, 8 November 2019.

21 Ibid. 
mengganggap dirinya tidak berguna ataupun gagal dalam menjadi kepala keluarga.

\section{Upaya Penanggulangan Tindak Pidana KDRT di Kota Makassar}

Upaya penanggulangan KDRT di Kota Makassar dilaksanakan oleh kepolisian dan Dinas Pemberdayaan Perempuan dan Perlindungan Anak (DPPPA) Kota Makassar melalui P2TP2A. Upaya penanggulangan KDRT di Kota Makassar dilakukan melalui 3 (tiga) tahap, yaitu:

\section{a. Upaya Preemtif}

Upaya preemtif dilakukan oleh pihak kepolisian untuk mencegah terjadinya tindak pidana. Bentuk upaya preemtif adalah menanamkan nilai/norma pada setiap orang. Meskipun ada kesempatan untuk melakukan pelanggaran/ kejahatan, tapi tidak ada niat-untuk melakukan hal tersebut, maka tidak akan terjadi kejahatan. Jadi, dalam usaha preemtif, faktor niat menjadi hilang meskipun ada kesempatan.

Berdasarkan wawancara dengan Makmur, Koordinator Tim Reaksi Cepat P2TP2A Kota Makassar, P2TP2A Kota Makassar mempunyai program sosialisasi akan bahaya KDRT, pelibatan tokoh masyarakat dalam kegiatankegiatan perlindungan perempuan dan anak, serta pelibatan pemerintah setempat yaitu RT, RW, dan Lurah. ${ }^{22}$

Ditambahkan oleh Muhammad Arif, Divisi Bantuan Hukum P2TP2A Kota Makassar, selain menggiatkan sosialisasi bahaya KDRT, P2TP2A juga melakukan pemetaan wilayah yang rawan terjadinya KDRT, serta mengidentifikasi faktorfaktor penyebab terjadinya KDRT. ${ }^{23}$

Berdasarkan wawancara dengan Aipda Darwis, Subnit II Unit VI (PPA) Satreskrim Polrestabes Makassar, aparat kepolisian melalui Sat Bhabinkamtibmas melaksanakan tugas untuk melakukan penyuluhan hukum/sosialisasi dalam mengedukasi masyarakat untuk menerapkan norma-norma positif untuk mencegah terjadinya KDRT. Fungsi Binmas juga mengadakan kunjungan "door to door" ke rumah masyarakat sambil memberikan penyuluhan tentang KDRT. ${ }^{24}$

\section{b. Upaya Preventif}

Upaya preventif merupakan upaya tindak lanjut dari upaya preemtif yang masih dalam tataran pencegahan sebelum terjadinya kejahatan. Dalam

22 Makmur, Upaya Penanggulangan Tindak Pidana Kekerasan dalam Rumah Tangga di Kota Makassar, diwawancara oleh Sutiawati, 8 November 2019.

23 Muhammad Arif, Upaya Penanggulangan Tindak Pidana Kekerasan dalam Rumah Tangga di Kota Makassar, diwawancara oleh Sutiawati, 11 November 2019.

24 Darwis, Upaya Penanggulangan Tindak Pidana Kekerasan dalam Rumah Tangga di Kota Makassar, diwawancara oleh Sutiawati, 11 November 2019. 
upaya preventif, yang ditekankan adalah menghilangkan kesempatan untuk melakukan kejahatan.

Mendasari wawancara dengan P2TP2A, upaya preventif yang dilakukan oleh P2TP2A Kota Makassar adalah sebagai berikut:

1) Pelatihan bagi kader/pendamping korban KDRT

Sekelompok warga diikutsertakan dalam pelatihan, didampingi, dan didorong untuk meningkatkan kemampuan mendampingi korban KDRT.

2) Pembentukan shelter warga

Shelter warga sebagai inovasi DPPPA

Kota Makassar, diharapkan mampu mengurai kekerasan terhadap perempuan dan anak. Shelter warga adalah sayap P2TP2A sebagai layanan pengaduan yang mampu membantu mengatasi persoalan yang kerap dihadapi perempuan dan anak, khususnya korban kekerasan. Shelter warga ini berbasis RT dan RW yang khusus menangani perempuan dan anak korban kekerasan, baik fisik maupun psikis. DPPPA memperkuat peran shelter warga di seluruh kecamatan yang ada di Kota Makassar untuk mencegah aksi kekerasan terhadap perempuan dan anak.
3) Pembentukan PATBM dan forum anak

Perlindungan anak terpadu berbasis masyarakat (PATBM) adalah sebuah gerakan dari jaringan atau kelompok warga pada tingkat masyarakat yang bekerja secara terkoordinir untuk mencapai tujuan perlindungan anak. Mengingat bahwa anak adalah pihak yang rentan mengalami kekerasan, baik di lingkungan masyarakat maupun di wilayah domestik rumah tangga. Oleh karena itu, forum anak diharapkan mampu mengenali, menelaah, dan mengantisipasi untuk mencegah dan melaksanakan perlindungan hukum terhadap anak di lingkungannya sendiri.

4) Pembentukan tim reaksi cepat Tim reaksi cepat P2TP2A Kota Makassar dalam mengemban tugas tak mengenal waktu libur, karena gencar menangani berbagai masalah kekerasan dan seksual.

5) Paralegal anak

Paralegal adalah sebutan bagi seseorang yang bukan advokat, namun memiliki pengetahuan dan keterampilan di bidang hukum (materil dan formil), serta HAM yang memadai. Paralegal anak didasarkan atas tingginya kasus-kasus kekerasan terhadap anak, eksploitasi, serta penelantaran keluarga. ${ }^{25}$

25 Makmur, Upaya Penanggulangan Tindak Pidana Kekerasan dalam Rumah Tangga di Kota Makassar, loc.cit. 


\section{c. Upaya Represif}

Upaya represif dilakukan pada saat telah terjadi tindak pidana/kejahatan yang tindakannya berupa penegakan hukum (law enforcement) dengan menjatuhkan hukuman. ${ }^{26}$ P2TP2A Kota Makassar telah menandatangani MoU dengan kepolisan terkait dengan perlindungan perempuan dan anak. Setiap kasus KDRT yang dilaporkan ke P2TP2A Kota Makassar akan diteruskan ke sentra pelayanan kepolisian, baik pada Polsek, Polrestabes Makassar, maupun Polda Sulsel sesuai wilayah hukum kasus KDRT yang terjadi. Penanganan kasus KDRT juga melibatkan lembaga swadaya masyarakat pemerhati perempuan dan anak.

Upaya Polri dalam menegakkan hukum kepada pelaku KDRT dilakukan dengan menjalankan penyelidikan dan penyidikan, menetapkan tersangka, dan menetapkan tindak pidana serta ancaman pidananya. Proses hukum terhadap pelaku KDRT diupayakan agar pelaku tidak mengulangi perbuatannya. ${ }^{27}$

\section{SIMPULAN}

Faktor penyebab terjadinya KDRT di Kota Makassar adalah penegakan hukum, rendahnya kesadaran hukum, masih kuatnya budaya patriarki, kondisi ekonomi/kemiskinan, lingkungan, dan kebiasaan minuman keras. Dari faktor-faktor tersebut, faktor kondisi ekonomi/kemiskinan menjadi faktor yang sangat berpengaruh terhadap terjadinya KDRT di Kota Makassar. Upaya penanggulangan KDRT di Kota Makassar dilakukan melalui upaya preemtif, preventif, dan represif yang dilakukan oleh P2TP2A Kota Makassar dan Polrestabes Makassar bekerja sama dengan masyarakat. Upaya yang penting dilakukan adalah dengan lebih menekankan upaya preventif untuk mencegah terjadinya KDRT di Kota Makassar.

\section{DAFTAR PUSTAKA}

Abbas, Ilham, Marten Bunga, Salmawati, Nurson Petta Puji, dan Hardianto Djanggih. "Hak Penguasaan Istri Terhadap Mahar Sompa Perkawinan Adat Bugis Makassar (Kajian Putusan PA Bulukumba Nomor 25/ Pdt.P/2011/PABlk)." Kanun: Jurnal Ilmu Hukum 20, No. 2 (2018): 203-218.

26 Elly Kurniawati, "Faktor Penyebab Terjadinya Kekerasan dalam Rumah Tangga dan Upaya Penanggulangannya (Suatu Tinjauan Kriminologis)," Jurnal Hukum Jatiswara 26, No. 3 (2011): 75-97, hlm. 91.

27 Darwis, Upaya Penanggulangan Tindak Pidana Kekerasan dalam Rumah Tangga di Kota Makassar, loc.cit. 
Abdurrachman,

Hamidah.

"Perlindungan Hukum Terhadap

Korban Kekerasan Dalam Rumah

Tangga dalam Putusan Pengadilan

Negeri Sebagai Implementasi Hak-

Hak Korban." Ius Quia Iustum Law

Journal 17, No. 3 (2010): 475-491.

Arif, Muhammad. Faktor Penyebab

Terjadinya Tindak Pidana Kekerasan dalam Rumah Tangga di Kota Makassar. Diwawancara oleh

Sutiawati, 8 November 2019.

\section{Upaya Penanggulangan}

Tindak Pidana Kekerasan dalam

Rumah Tangga di Kota Makassar.

Diwawancara oleh Sutiawati, 11

November 2019.

Arini, Resti. "Kekerasan Psikis dalam

Rumah Tangga Sebagai Suatu Tindak

Pidana." Lex Crimen II, No. 5 (2013):

32-42.

CR-7. "Pembuktian Masih Menjadi Momok Penanganan Kasus KDRT: Bagaimana Mendefinisikan

Kekerasan Psikis, Apakah Dia Harus

Depresi, atau Cukup Dia Mulai Gelisah?" Hukumonline.com, 2010. https://www.hukumonline.com/ berita/baca/lt4b459ec464a39/kdrt/.

Darwis. Faktor Penyebab Terjadinya Tindak Pidana Kekerasan dalam Rumah Tangga di Kota Makassar. Diwawancara oleh Sutiawati, 8 November 2019.
Upaya Penanggulangan

Tindak Pidana Kekerasan dalam

Rumah Tangga di Kota Makassar.

Diwawancara oleh Sutiawati, 11

November 2019.

Desti, Silvia. Faktor Penyebab Terjadinya Tindak Pidana Kekerasan dalam Rumah Tangga di Kota Makassar. Diwawancara oleh Sutiawati, 8 November 2019.

Fanani, Estu Rakhmi. “Undang-Undang Nomor 23 Tahun 2004 Tentang Kekerasan dalam Rumah Tangga, Antara Terobosan Hukum dan Fakta Pelaksanaannya." Jurnal Legislasi Indonesia 5, No. 3 (2008): 1-8.

Harnoko, B.Rudi. "Dibalik Tindak Kekerasan Terhadap Perempuan." Muwazah 2, no. 1 (2010): 181-188.

Hidajat, Monica, Angry Ronald Adam, Muhammad Danaparamita, dan Suhendrik. "Dampak Media Sosial dalam Cyber Bullying." Comtech 6, No. 1 (2015): 72-81.

Jamaa, La. "Perlindungan Korban Kekerasan dalam Rumah Tangga dalam Hukum Pidana Indonesia." Jurnal Cita Hukum II, No. 2 (2014): 249-272.

Kolibonso, Rita Serena. "Penegakan Hukum Kejahatan Kekerasan dalam Rumah Tangga." Jurnal Legislasi Indonesia 5, No. 3 (2008): 35-44. 
Kurniawati, Elly. “Faktor Penyebab Terjadinya Kekerasan dalam Rumah Tangga dan Upaya Penanggulangannya (Suatu Tinjauan Kriminologis)." Jurnal Hukum Jatiswara 26, No. 3 (2011): 75-97.

Makmur. Faktor Kesadaran Hukum dalam Tindak Pidana Kekerasan dalam Rumah Tangga di Kota Makassar. Diwawancara oleh Sutiawati, 11 November 2019.

\section{Upaya Penanggulangan}

Tindak Pidana Kekerasan dalam Rumah Tangga di Kota Makassar. Diwawancara oleh Sutiawati, 8 November 2019.

Mulyana, Rachmat. "Penanaman Etika Lingkungan Melalui Sekolah Perduli dan Berbudaya Lingkungan." Jurnal Tabularasa Pps Unimed 6, No. 2 (2009): 175-80.

Nurhayati, Siti Rohmah. "Atribusi Kekerasan dalam Rumah Tangga, Kesadaran Terhadap Kesetaraan Gender, dan Strategi Menghadapi Masalah pada Perempuan Korban Kekerasan dalam Rumah Tangga." Jurnal Psikologi UGM 32, No. 1 (2005): 1-13.

Nuryani, Rena Yulia. "Perlindungan Hukum Terhadap Korban Kekerasan dalam Rumah Tangga dalam Penegakan Hukum." Mimbar: Jurnal
Sosial dan Pembangunan 20, No. 3 (2004): 311-326.

Perempuan, Reporter Komnas. "Hentikan Impunitas Pelaku Kekerasan Seksual dan Wujudkan Pemulihan yang Komprehensif Bagi Korban." Siaran Pers Catatan Tahunan (CATAHU) Komnas Perempuan, 2019. https://www. komnasperempuan.go.id/readnews-siaran-pers-catatan-tahunancatahu-komnas-perempuan-2019.

Sukmawati, Bhennita. "Hubungan Tingkat Kepuasan Pernikahan Istri dan Coping Strategy dengan Kekerasan dalam Rumah Tangga." Jurnal Sains dan Praktik Psikologi 2, No. 3 (2014): 205-218.

Wulandari, Lely. “Kebijakan Penanganan Kekerasan dalam Rumah Tangga Melalui Mediasi Penal." LAW REFORM 4, No. 1 (2008): 1-19.

Yulia, Rena. "Implementasi UndangUndang Nomor 23 Tahun 2004 Tentang Penghapusan Kekerasan dalam Rumah Tangga dalam Proses Penegakan Hukum (Sebuah Solusi dalam Perlindungan Hukum Terhadap Korban)." Pro Justitia 24, No. 3 (2006): 292-300. 